\title{
The Effect of Kahoot As an Ice Breaker on EFL Students' Motivation
}

\author{
Ni Luh Rahayu Artati \\ Universitas Pendidikan Ganesha, Indoensia \\ artati.rahayu.17@gmail.com
}

\begin{abstract}
Teachers are encouraged to increase students' motivation by implementing innovative techniques and strategies. Ice breaker is one of teaching technique that can improve students' learning motivation in which it provides a fun learning activity. The current study investigated the effect Kahoot as an ice breaker on EFL students' motivation. This study was an experiment with posttest only control group design. The data were collected from a motivation questionnaire and analyzed using descriptive and inferential statistics. The results showed that students in experiment group shows higher level of motivation compared to students in control group. The result of $t$ test showed that the mean difference between groups are significant. Thus, it can be concluded that Kahoot as an ice breaker effected EFL students' motivation in learning.
\end{abstract}

Keywords: EFL, Kahoot, Motivation

\section{INTRODUCTION}

Teaching English as a foreign language is quite challenging, considering that the students have rare opportunities to learn English at the outside of the class. The main challenge that should be faced by EFL teachers is students' motivation itself. Wagiyo (2018) states that most of EFL students have a lower motivation in learning English and they regarded English as a compulsory subject for completing the need of examination passing level. Bridgeland et al (2006) argues that EFL students face a significant academic challenge, in spite they highly confident in passing their academic. It is said that students cannot have a smooth progress because of several factors, such as: their perception that school is boring, unmotivated feeling, multiple academic challenges, and their personal situations. In addition, it is said that motivation is a crucial personality factor of the students in producing a foreign language viewed from their psychological aspect. Therefore, a teaching approach which covers elements that can encourage students' motivation and engage them in language is needed to achieve a successful learning process (Yürük, 2019). It can be seen that students cannot make a progress mastering foreign language because of their low motivation.

There are many teaching techniques that ave been suggested for the teachers to motivate students during the learning process. Ice breaker is one of the techniques that suitable to be implemented in motivating students to learn English. Chlup and Collins (2010) say that the implementation of icebreakers in teaching adult learners is effectively for improving students' participation, increased student persistence, and ultimately enhanced students' learning. Ice breaker is used in creating a space that allows the adult learners to establish trust, develop safe learning environments, and assist with content learning. That 
statement is supported by the definitions of ice breaking stated recently which said that ice breaking is an activity done based on students' needs and undertaken to break the boring, rigid, and passive learning atmosphere into a learning activity that is fun, refreshing, active, and arouses students' learning motivation to feel more passionate toward the learning process itself (Pratiwi, 2013;Susanah \& Alarifin, 2014;Fanani, 2017). Commonly, some teachers implement ice breaker as an instruction for improving students' motivation to communicate each other and handling some problems appear in a class such as boredom, tired, low enthusiasm, and unwillingness to study (Panggua, 2016). It is also said that using an appropriate ice breaker is important in an English language learning because it helps teacher in organizing the students for getting a better understanding toward the lesson which influences the level of their achievement (Yeganehpour, 2016). An appropriate kind of ice-breaking activity will make students have a fun learning process that can influence their comprehension toward a lesson.

Since technology has a high integration in $21^{\text {st }}$ century learning, it gives a wide chance for the teachers to use technology for enhancing students' motivation, considering that students are recently known as millennials. Mohd Muhridza et al (2018) state that students in this era are called as millennials who have a better ability in mastering a certain aspect of technology. It is believed that teachers need to explore and combine new technology and their knowledge to achieve a meaningful teaching and learning experience. The previous theory states that students can get a valuable language experience through technology in which technology is the denominator between gamification and language learning (Ybarra \& Green, 2003) .Therefore, the integration of technology in education field enable teachers to create an innovative teaching strategy for attaining students' interest and motivation in learning English as foreign language.

Based on the statement above, a positive learning environment can be formed through the combination between technology and an appropriate teaching technique, for instance; using Kahoot as an ice breaker. Kahoot is a game-based learning tool that commonly used in language learning process in which it is believed as an effective way. It is relevant to the statement shows by Damara (2016), Kahoot is one of media which is applied as an ice-breaking that consists of online quizzes. Kahoot is a tool for using technology to administer quizzes, discussions or surveys. It is a game-based classroom response system played by the whole class in real-time. Multiple-choice questions are projected on the screen. Students answer the questions with their smartphone, tablet or computer. By using this application, teachers can eventually save time and paper, while collaborating more effectively with students. It indicates that Kahoot can be used as a game tool in which game is covered as one of ice-breaker technique as what Hutasoit and Tambunan (2018) show that there are nine kinds of ice-breaking technique namely: yel-yel, clap hands, body movement, song, games, joke, story, magic, and audio-visual.

Kahoot is a free application which is designed as a game-based learning that can be used to engage students during the learning process, in case it also can be used for any kind of activity whether it is for business or social activity. A recent definition of Kahoot stated by Setiawan \& Soeharto (2020) Kahoot is an application which provides a quiz answering practice which is also completed by back sound music and it can enhance student's interest to not feel bored while playing the quiz. Kahoot is available on Google Play store where the users can download it by smartphone and it is free. The earlier theory describes Kahoot as 
a free game-based learning platform for all ages that can be used as a fun learning for any subject, any language, and it can be used on any device (Euro, 2015).

Kahoot offers an unlimited player as its special quality in which it can be played in a group or individually. Susanti (2017) states that Kahoot is usually created by teachers, students, business people, and social users consists of a specific topic and it can be used in real time for an unlimited number in which it provides a social, fun, and game like learning environment. In addition, Kahoot is free to be downloaded that can make students easier to install Kahoot in their smartphone or laptop. Yürük (2019) defines Kahoot as the most popular gamification tool that is chosen to be used in the class. It is a free online gamebased application offers many options, such as; quizzes, discussions, and surveys which create the learning process becomes challenging, fun, and engaging. Siegle (2015) shows a specific description about Kahoot in which it is described as a simple free multimedia or online multimedia used by teachers and students. It has a limited character up to 95 for the question and the answer is only provided for 65 . Kahoot contains of pictures and videos in which the players or users give a time limit to answer the questions provided. This application can be installed or accessed via laptop, smart-phones, or other devices. He also recommends Kahoot as an online game for testing students' knowledge on English reading skills.

The results of observations through interviews with teachers at one school in Singaraja found that teachers saw low student motivation. This can be seen from the learning process where students are not active and often do not follow the teacher's instructions. Seeing the importance of increasing learning motivation, this study intended to explore the effect of Kahoot as an ice breaker on EFL students' motivation.

\section{METHOD}

The current study was an experimental study. The design of the study was posttest only control group design. There are two variables in this study namely independent variable (Kahoot) and dependent variable (motivation). This study was conducted in one private school in Singaraja, Bali and followed by 40 students. 20 students in experimental group, 20 students in control group. The experiment group was taught with Kahoot while in control group the students were taught with conventional teaching.

In collecting the data, this study used motivation questionnaire. The motivation questionnaire was adopted from Gardner's attitude and motivation as cited in (Zafarghandi \& Jodai, 2012). The data were analyzed using descriptive and inferential analysis.

\section{FINDINGS \& DISCUSSIONS}

After conducting experiment, students' motivation score was collected. Table 1 presents the students' motivation in experiment and control group. 
The Art of Teaching English as a Foreign Language, Vol.2 No.2 2021

p-ISSN : 2656-8942, e-ISSN : 2684-8546

DOI: $10.36663 /$ tatefl.v2i2.121

Table 1. Findings

\begin{tabular}{rrr}
$N$ & Control & Experiment \\
\hline 1 & 3.50 & 3.90 \\
\hline 2 & 3.35 & 3.80 \\
\hline 3 & 3.40 & 3.75 \\
\hline 4 & 3.40 & 4.30 \\
\hline 5 & 3.35 & 3.95 \\
\hline 6 & 3.40 & 4.00 \\
\hline 7 & 3.65 & 3.95 \\
\hline 8 & 3.40 & 3.75 \\
\hline 9 & 3.20 & 4.00 \\
\hline 10 & 3.20 & 4.25 \\
\hline 11 & 3.40 & 3.85 \\
\hline 12 & 3.45 & 3.30 \\
\hline 13 & 3.40 & 3.85 \\
\hline 14 & 3.25 & 4.25 \\
\hline 15 & 3.65 & 3.85 \\
\hline 16 & 3.60 & 4.30 \\
\hline 17 & 3.45 & 3.80 \\
\hline 18 & 3.55 & 3.65 \\
\hline 19 & 3.35 & 3.90 \\
\hline 20 & 3.45 & 3.85
\end{tabular}

From Table 1, it can be seen that highest score in control group is 3.65 and the lowest score is 3.20 so the range is 0.45 . Meanwhile in experiment group, the highest score in control group is 4.30 and the lowest score is 3.30 so the range is 1.00 . In order to identify the criteria of motivation level, motivation category was created as shown in Table 2.

Table 2 Motivation Level Category

\begin{tabular}{cc} 
Mean Range & Category Level of Motivation \\
\hline $3.68-5.00$ & High \\
\hline $2.34-3.67$ & Moderate \\
\hline $1.00-2.33$ & Low
\end{tabular}

There are three categories namely high, moderate, and low based on the mean range of motivation. The frequency of students' level of motivation is presented in Figure 1. 
Figure 1. Motivation Level
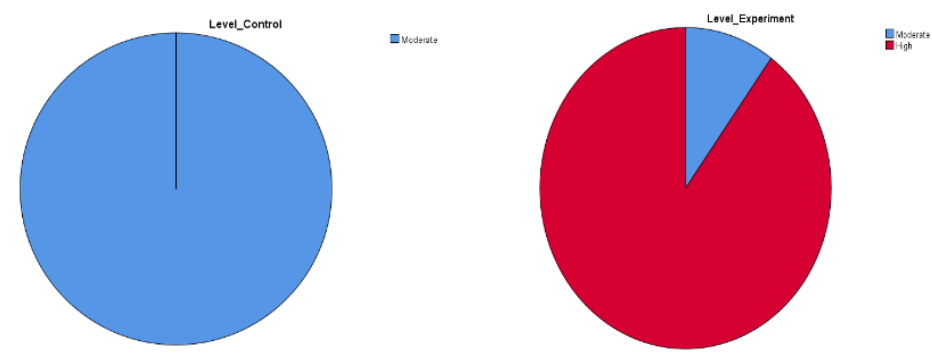

In Figure 1, it can be seen that in control group, 100\% students are belonged to moderate level of motivation. Meanwhile in experiment group, $10 \%$ belong to moderate and $90 \%$ students belong to high level of motivation.

The next analysis conducted was descriptive and inferential analysis. The result can be seen in Table 3 .

Table 3. Descriptive and Inferential Analysis

\begin{tabular}{cccccc} 
Mean & $\begin{array}{c}\text { Standard } \\
\text { Deviation }\end{array}$ & $\begin{array}{c}\text { Normality } \\
\text { (Kolmogorov- } \\
\text { Smirnov) }\end{array}$ & $\begin{array}{c}\text { Homogeneity } \\
\text { (Levene } \\
\text { Statistic) }\end{array}$ & $\begin{array}{c}\text { Independent } \\
\text { sample t } \\
\text { test (Sig. 2- } \\
\text { tailed) }\end{array}$ \\
\hline Control & 3.42 & .127 & .175 & \multirow{2}{*}{.071} & 0.001
\end{tabular}

All mean score from groups was summarized and it was found that the mean score of control group is 3.42 while the mean score experiment group is 3.91. By looking at the mean score, it can be stated that the mean score of experiment is higher than the mean score of control group $(3.91>3.42)$.

To test if the mean difference between group is significant or not, a t test was conducted. Before conducting t test an assumption test was conducted first. This includes identifying the normality and homogeneity of the data. From Table 1 it can be seen that, the value of Kolmogorov-Smirnov for control group is .175 while for experiment group is .200. Since the value of Sig. for pretest and posttest is higher than .05, the data are categorized normally distributed. Meanwhile the data are categorized homogeneous if the value of Sig. from Levene statistic is higher than .05. It was found that the value of Levene statistic is .071 which is higher than .05. Therefore, the data are homogeneous.

From the result of independent sample t test (Sig. 2-tailed), the value obtained was .001. A significant mean difference is indicated if the value of Sig. 2tailed is lower than .05. Since the obtained value was .001 , this indicates that there is a significant mean difference between experiment and control group. The result of effect size test shows 2.568 which indicates a large effect.

The result of the current study confirmed that there is a significant mean difference between students' motivation in control group who were taught with conventional teaching and students in experiment group who were taught with Kahoot. Using Kahoot in language teaching is really important, remembering that 
Kahoot has several advantages for EFL teachers. Kahoot creates a fun learning environment that breaks students' boringness and increase students' learning motivation. Damara (2016) on his study shows the effectiveness of using Kahoot in movie interpretation class. The study shows that the students gives a positive reaction in which the use of Kahoot helps them to have a fun learning process. in addition, it points out that Kahoot motivates them to have a deeper understanding toward movie interpretation class. The students also give suggestions toward the implementation of Kahoot as an ice breaker when they are asked by the questionnaire for showing their perception. Most of students say that the internet connection and the usage frequency have to be developed well in order to get a better performance of the use Kahoot as an ice breaking session. A further study that concerns on the use of Kahoot for enhancing students' engagement and improving their motivation has been conducted at a research-intensive teaching university in New Zealand. By conducting a semi structured interview, it is found that Kahoot has a highest influence toward classroom dynamics, engagement, motivation and improved learning experience in which it shows that Kahoot can enrich the students' learning quality in the classroom (Licorish et al., 2017). Those studies prove that Kahoot has a high influence towards students' learning motivation in which it shows through their active engagement in the classroom during the learning process.

Kahoot also provides a wide chance for students to practice and improve their language skills. The integration of Kahoot in language learning influences and enhances a language learning outcome and creates a positive learning environment. A study reports a small-scale survey which is conducted among 50 secondary students. It is found that the participants experience a positive learning process when Kahoot is integrated in their class. It shows that they actively engage in their language lessons. Most of the participants report that they experience a more meaningful and rich language learning where they can explore their language skills (Kaur, 2019). Chotimah and Rafi (2018) conducts a research which focuses on the use of Kahoot as a teaching media for English Department students. The study uses experimental research design and it is found that the significant value is 0.02 , it is lower than the significant level 0.05 . it can be inferred that Kahoot is effective in influencing students' reading skills. However, Kahoot is believed as an attractive game-based features for students particularly if it is used in language learning activities that allows students to explore their language skills with their mates or peers synchronously and get an actual reaction (Kaur \& Nadarajan, 2020).

In addition, using Kahoot as an ice breaker also helps teachers to assess their students indirectly. Kaur and Nadarajan (2020) shows that Kahoot is enjoyable assessment tool. It is shown through a study where the participants report their perspectives on the use of Kahoot. They enjoy play Kahoot as an assessment tool and it is claimed that Kahoot becomes an ice-breaker too and creates and energetic and fun learning that brings a competition moment that will improve the classroom atmosphere. It is also stated that Kahoot is an alternative assessment for the teachers whereby the results, scores and percentages of the questions can be recorded online and downloaded manually too. Furthermore, Kahoot as assessment can be controlled after the test or quiz is completed. It allows students to be more aware of their strength and weaknesses and it brings a new experience for the students (Nurhadianti \& Pratolo, 2020). It is also supported by Adnyani et al (2020) who state that EdWeek Market Brief publishes 
a recent study reveals that Kahoot is listed no. 5 out of 40 most popular digital learning tools in K-12 schools accessed by a browser, and ranked no. 1 in the assessment category.

\section{CONCLUSIONS}

Kahoot has many benefits in language teaching, therefore it is important to use Kahoot as an ice breaker in order to improve students' learning motivation particularly for EFL students who have a low motivation. Kahoot is effective to create a fun learning environment that influence students' motivation in which it can be seen through the studies conducted by several researchers before. The engagement of the students through the use of Kahoot in language teaching shows that they have a higher motivation to learn and Kahoot involves them to actively participate in the classroom. Kahoot provides an opportunity for students to practice their language skills. Kahoot has been implemented as teaching media, particularly in teaching reading. It is found that the students experience an enrich language learning where they can explore their language skills and face an improvement in their reading skills. The last, Kahoot can be used as an assessment tool while the teachers are using Kahoot as an ice breaker. It is proved by the studies and theory about the existence of Kahoot as an assessment tool. The teachers are able to record and download the result of the quiz given for the students as an ice breaker as a data to evaluate or assess students' knowledge. It can be concluded that Kahoot is essential to be implemented in language teaching.

EFL learners have a rare opportunity to speak English in their daily life because they usually speak their mother tongue for the daily communication. It brings some challenges to the teachers in teaching English as a foreign language where students' motivation itself is one of challenge that should be faced by the teachers. Motivation is an essential factor that influences the successful learning process. In this case, most of EFL students have a low motivation in learning English. Considering that problem, implementing the appropriate teaching technique is needed to improve students' learning motivation. Ice breaker is the teaching technique that can be implemented to increase students' learning motivation and encourage them to give a positive reaction during the learning process through a fun way. Ice breakers provides some activities to be implemented by the teacher, one of them is games. Since technology has an important role in education field in $21^{\text {st }}$ century, there are so many teaching platform or media that can be used by the teachers. One of them is Kahoot in which it is an application designed as game-based learning.

\section{REFERENCES}

Adnyani, K. E. K., Adnyana, I. W., \& Murniasih, N. N. (2020). Teacher and Students' Perception on Using Kahoot! for English Learning. 3rd International Conference on Innovative Research Across Disciplines (ICIRAD 2019) Teacher, 394(Icirad 2019), 62-67. https://doi.org/10.2991/assehr.k.200115.011

Bridgeland, J. M., Dilulio, John J., J., \& Morison, K. B. (2006). The Silent Epidemic: Perspectives of High School Dropouts. In Civic Enterprises (Issue March). http://eric.ed.gov/?id=ED513444

Chlup, D. T., \& Collins, T. E. (2010). Breaking the Ice: Using Ice-breakers and Reenergizers with Adult Learners. Adult Learning, 21(3-4), 34-39. 
https://doi.org/10.1177/104515951002100305

Chotimah, C. I., \& Rafi, M. F. (2018). The Effectiveness of Using Kahoot as a Media in Teaching Reading. E-Link Journal, 5(1), 19-29.

Damara, G. (2016). Students' perception on the use of kahoot as an ice breaker in movie interpretation class. JELTIM (Journal of English Language Teaching Innovations and Materials), 3(1), 63-74.

Euro, E. (2015). "Digischool, Kahoot!! And RefME Announced as Winners of 2015 EdTech 20. Www. Prnewswire.Com.

Fanani, A. (2017). Ice Breaking Dalam Proses Belajar Mengajar. 6(11), 1-7. https://doi.org/10.1145/3110292.3110316

Hutasoit, R., \& Tambunan, D. B. (2018). The Effect of Ice Breaking Technique in Teaching Speaking at the Tenth Grade Students of SMK Dharma Bhakti Siborongborong in Academic Year 2018/2019. International Journal of English Literature and Social Sciences, 3(5), 700-705. https://doi.org/10.22161/ijels.3.5.2

Kaur, P. (2019). Kahoot! In the English Language Classroom. South East Asia Journal of Contemporary Business, Economics and Law, 20(6), 49-54.

Kaur, P., \& Nadarajan, R. (2020). Language Learning and Teaching Using Kahoot. International Journal of Modern Education, 2(5), 19-28. https://doi.org/10.35631/lJMOE.25003

Licorish, S. A., Owen, H., \& Daniel, B. K. (2017). “ Go Kahoot!” Enriching Classroom Engagement, Motivation and Learning Experience with Games. Proceedings of the 25th International Conference on Computers in Education., December, 755-764.

Mohd Muhridza, N. H., Mohd Rosli, N. A., Sirri, A., \& Abdul Samad, A. (2018). Using Game-based Technology, KAHOOT! for Classroom Engagement. LSP International Journal, 5(2), 37-48. https://doi.org/10.11113/lspi.v5n2.77

Nurhadianti, \& Pratolo, B. W. (2020). Students ' Perception toward the Application of Kahoot! as an Assessment Tool in EFL Class. Universal Journal of Research, $8(5)$, 2150-2155. https://doi.org/10.13189/ujer.2020.080554

Panggua, S. (2016). The Effectiveness of Ice-Breaker Activity to Improve Students ' Speaking Skill of The Third Semester Students of English Department Students of FKIP UKI Toraja. Tefl Overseas.

Pratiwi, I. A. (2013). Pengaruh Penggunaan Ice Breaker Terhadap Motivasi Belajar Anak Kelompok B Di Tk Laboratorium Pg-Paud Fip Unesa. PAUD Teratai, 2(3), 1-7.

Setiawan, A., \& Soeharto, S. (2020). Kahoot-Based Learning Game to Improve Mathematics Learning Motivation of Elementary School Students. Al-Jabar: Jurnal Pendidikan Matematika, 11(1), 39-48. https://doi.org/10.24042/ajpm.v11i1.5833

Siegle, D. (2015). Technology: Learning Can Be Fun and Games. Gifted Child Today, 38(2), 192-197. Zarzycka-Piskorz.

Susanah, R., \& Alarifin, D. H. (2014). Penerapan Permainan Penyegar (Ice Breaking) Dalam Pembelajaran Fisika Untuk Meningkatkan Motivasi Dan Hasil Belajar. Jurnal Pendidikan Fisika, 2(1), 42-50. https://doi.org/10.24127/jpf.v2i1.104

Susanti, S. (2017). Fun Activities in Teaching Enlish by Using Kahoot! 2nd International Seminar on Education 2017 Empowering Local Wisdom on Education for Global Issue, 453-458. 
Wagiyo, S. (2018). Analysis of Students 'Motivation in Learning English at Senior High Schools. October.

Ybarra, R., \& Green, T. (2003). Using Technology to Help ESL/EFL Students Develop Language Skills,. The Internet TESL Journal, 9(3).

Yeganehpour, P. (2016). Using Ice-Breakers In Improving Every Factor Which Considered Using Ice-Breakers In Improving Every Factor Which Considered. April.

Yürük, N. (2019). Edutainment: Using Kahoot! As A Review Activity in Foreign Language Classrooms. Journal of Educational Technology and Online Learning, 2(2), 89-101. https://doi.org/10.31681/jetol.557518

Zafarghandi, A. M., \& Jodai, H. (2012). Attitudes toward English and English Learning at an Iranian Military University: A Preliminary Survey. International Journal of Social Sciences and Education, 2(1), 102-123. 